\title{
Attention, Interest, Search, Action, and Share (AISAS) Analysis of Zomato Promotion Effectiveness
}

\author{
Putri Utami Ruswandi ${ }^{\text {*; }}$ Hartoyo ${ }^{2}$; Mukhamad Najib ${ }^{3}$ \\ ${ }^{1}$ School of Business and Economics, Universitas Prasetiya Mulya \\ Jln. RA. Kartini (Tb. Simatupang), Jakarta Selatan 12430, Indonesia \\ ${ }^{1-3}$ School of Business, Master of Management, Institut Pertanian Bogor University \\ Jln. Raya Pajajaran, Jawa Barat 16128, Indonesia \\ ${ }^{1}$ putri.sbipb.e70@gmail.com; ${ }^{2}$ hartoyo@ipb.ac.id; ${ }^{3}$ najib@apps.ipb.ac.id
}

Received: $3^{\text {rd }}$ September 2020/ Revised: $19^{\text {th }}$ October 2020/ Accepted: $16^{\text {th }}$ November 2020

How to Cite: Ruswandi, P. U., Hartoyo, \& Najib, M. (2021). Attention, Interest, Search, Action, and Share (AISAS)

Analysis of Zomato Promotion Effectiveness. Binus Business Review, 12(2), 177-188.

https://doi.org/10.21512/bbr.v12i2.6676

\begin{abstract}
Current technological advances, especially the Internet of Things (IoT), are widely used by people in their daily lives to transact, communicate, and find various information. The research analyzed the effectiveness of promotions carried out by companies based on the concept of marketing communication from technological developments, namely the Attention, Interest, Search, Action, and Share (AISAS) model, and how to increase consumer purchases. The research applied a descriptive approach by distributing questionnaires to Zomato Gold members, with a sample size of 180 people. Data analysis applied Structural Equation Modeling (SEM) to see the relationship between promotion, attention, interest, search, action, and share variables. The finding shows that the effectiveness of promotional advertising based on the AISAS model is not significant enough to encourage consumers to make purchases by visiting restaurants with Zomato Gold benefits. Therefore, Zomato needs to increase promotional activities on social media to increase consumers' attention regarding these promotions by maximizing social media features. The increase in consumers' attention to promotions will increase their opportunities to be interested, seek information, make purchases, and share information and experiences with others. However, when consumers pay attention to a promotion, they are not immediately interested in the advertisement. So, it is necessary to study other factors, such as internal factors that affect consumers, apart from external factors that influence consumers' interest and purchasing decisions.
\end{abstract}

Keywords: Attention, Interest, Search, Action, and Share (AISAS), promotion effectiveness, Zomato

\section{INTRODUCTION}

Current technological advances, especially the Internet of Things (IoT), are widely used by people in their daily lives to transact, communicate, and find various information. The projection of Internet users in Indonesia in 2020 is estimated to reach 199 million people based on Figure 1 (Nurhayati-Wolff, 2020). The projection results show that Internet users will increase, and the Internet is necessary for society in the digital era.

The Internet is not only used to find information but also to interact with people. Humans are social creatures, so that various social networking sites have emerged to facilitate the interaction. The most wellknown social networking sites are Facebook, YouTube, WhatsApp, Instagram, and Twitter (Katadata, 2020). The interactions that occur are not only communication but also the share of various kinds of information. Internet users' interaction is not limited to one area, but they can interact with other users in different parts of the world. It is also not limited by time and can be done anytime and anywhere.

Companies widely use this opportunity to market products or services offered by using marketing communications that take advantage of Internetbased IoT. Besides having an impact on marketing communications, IoT can also expand the scope of 


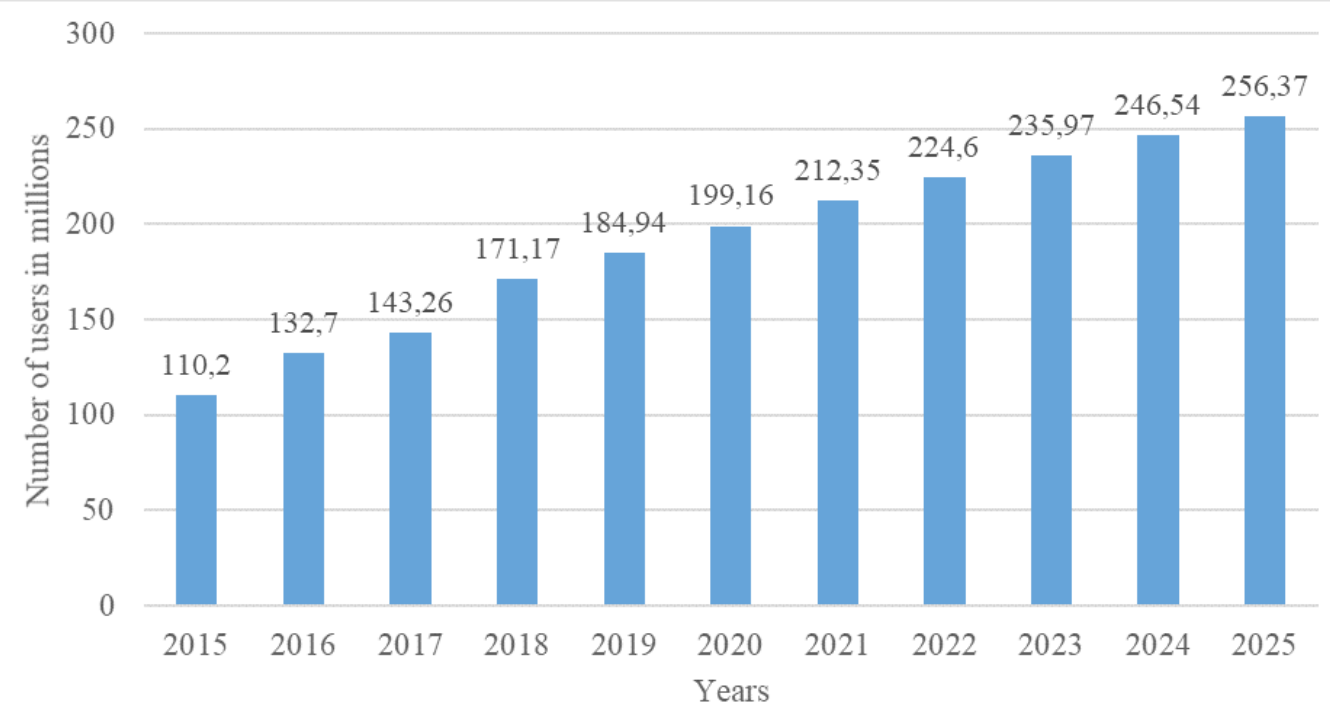

Figure 1 Projection of Internet Users in Indonesia 2015-2025

marketing related to advertising analysis (Shah \& Murthi, 2020). The Internet is used in business for promotional media, product catalogs, and information exchange (Stephen, 2016). Marketing using the Internet is called digital marketing. For example, the marketing activities with various web-based media are search platforms, advertisement platforms, social media, transactional platforms, and service platforms (Rangaswamy et al., 2020).

The advantages of digital marketing for companies are better brand awareness, lower marketing costs, and increased sales (Dwivedi et al., 2021). Moreover, corporate social media can advertise or communicate more efficiently (Akram \& Kumar, 2017). The most popular digital marketing tools are Facebook, Instagram, and WhatsApp (Sharma, Sharma, \& Chaudhary, 2020).

Digital marketing is more scalable and interactive (Piñeiro-Otero \& Martínez-Rolán, 2016). It is a promotion with all forms of digital advertising to reach market segments (Mandal, Joshi, \& Sheela, 2016). In addition, consumers are very active in using social media, allowing companies to interact with them through social media to get feedback about their products (Algharabat, Rana, Dwivedi, Alalwan, \& Qasem, 2018). Similarly, social media is used by consumers to find information to support decisionmaking (Bu, Parkinson, \& Thaichon, 2020).

Promotion is a way for companies to communicate with consumers using a promotional mix (Kotler \& Keller, 2016). It is carried out by companies to increase product sales (McAlister, Srinivasan, Jindal, \& Cannella, 2016). The sales promotion has a significant and positive effect on consumers' purchase intentions, but price discounts have an insignificant impact on it (Bhatti, 2018).

Consumer behavior focuses on making consumers' decisions, meeting needs, buying products, and using services (Tang, Hao, \& Feng, 2020). The consumption stage starts with a pre-purchase problem. Consumers decide that they need a product and the best source of information to learn more about alternative options. The next stage of purchase focuses on whether acquiring the product is a pleasant or stressful experience. The last step after purchase is whether the product is as expected or not. Consumer behavior can be evaluated from the determinants that affect the purchasing process and the decision-making process with the purchases (Oke, Kamolshotiros, Popoola, Ajagbe, \& Olujobi, 2016).

Nevertheless, the Internet also impacts changing consumer behavior, especially at the stages of the purchase decision process (Abou-Elgheit, 2018). Therefore, it is relevant to marketing communications developed from technological developments, namely the Attention, Interest, Search, Action, and Share (AISAS) model (Sugiyama \& Andree, 2011). Marketing communication is based on technological developments, especially the Internet, and changes in consumer behavior due to technological developments. Consumer behavior with the Internet is considered more accurately described by the AISAS model.

AISAS model is a basic framework for decisionmaking resulting from reactions to promotional activities. Consumers' attention and interest in products in the AISAS model are obtained from advertisements and promotional messages displayed through digital media. The last three stages in the AISAS model involve consumers to search, act, and share. Search and share activities are relevant to consumers who interact via social networking sites or use smartphones.

The Internet impacts the emergence of social networks and online reviews as a new source of information for consumers (Ratchford, 2020). The search and analysis results of the obtained information are followed by the action stage for purchasing the product. Consumers have evaluated and gained 
experience using the offered products. In the next stage, consumers will share the results of evaluations and experiences in using these products via the Internet. Consumers share experiences on social media based on their experiences and emotions. Hence, it becomes a form of electronic word of mouth (eWOM) (Kim \& Fesenmaier, 2017).

Online consumers' reviews and ratings are influential against purchasing decisions (Ardianti \& Widiartanto, 2019). The review and rating variables are proven to have a significant relationship to the users' purchase interest in the online marketplace in Indonesia. Text-based reviews have had an impact more significant than rating-based reviews (Farki, Baihaqi, \& Wibawa, 2016). Consumers make judgments about products after reading reviews. When evaluating reviews, consumers focus on the negative side of the review (Zhang, Zheng, \& Wang, 2020). Negative reviews are considered important information for consumers to rate products. So, the importance of review is to reduce the uncertainty and risk felt by consumers (Zhang et al., 2020).

The research will analyzes the effectiveness of promotion based on the AISAS model analysis because the model is very relevant to the activities in Zomato. Zomato is a restaurant dictionary application with various restaurant information. The information includes the name of the restaurant, address, menu, and price. Restaurant owners or Zomato members can upload restaurant and food photos on the application. Moreover, Zomato members can give ratings to restaurants that have been visited by writing ratings and reviews on the application. Zomato issues a paid membership (Zomato Gold) with benefits of $1+1$ food or $2+2$ drinks at restaurants that work with Zomato Gold (Putri, 2019). Promotional advertisements regarding Zomato Gold are mostly carried out through social media, especially on Instagram, because most Zomato users are aged 25-34 years (Reily, 2019).

Promotional activities carried out by Zomato on social media provide information about Zomato Gold and restaurants. These activities are expected to attract consumers' attention. When Zomato Gold members have seen promotions on social media, they will likely be interested in the conveyed information, such as restaurants and the menus. Interest in this information makes Zomato Gold members seek additional information through the Zomato application or ask directly to people who have visited the restaurant. The obtained information from these activities can encourage consumers to visit restaurants by utilizing the benefits of Zomato Gold. After visiting the restaurant, consumers are expected to provide reviews and recommendations to others through the Zomato application.

The total number of Zomato Gold members is 100.000 people. However, those who make purchase transactions are only $4 \%$ of all Zomato Gold members (Putri, 2019). So, the research needs to be done to analyze the effectiveness of promotional advertisements carried out by Zomato on social media regarding purchasing decisions of Zomato Gold members based on the AISAS model. It also seeks solutions to increase the purchase of Zomato members based on the results of this analysis.

Based on the theoretical study described, the hypothesis is based on modifying or developing the AISAS model using the promotion variable as

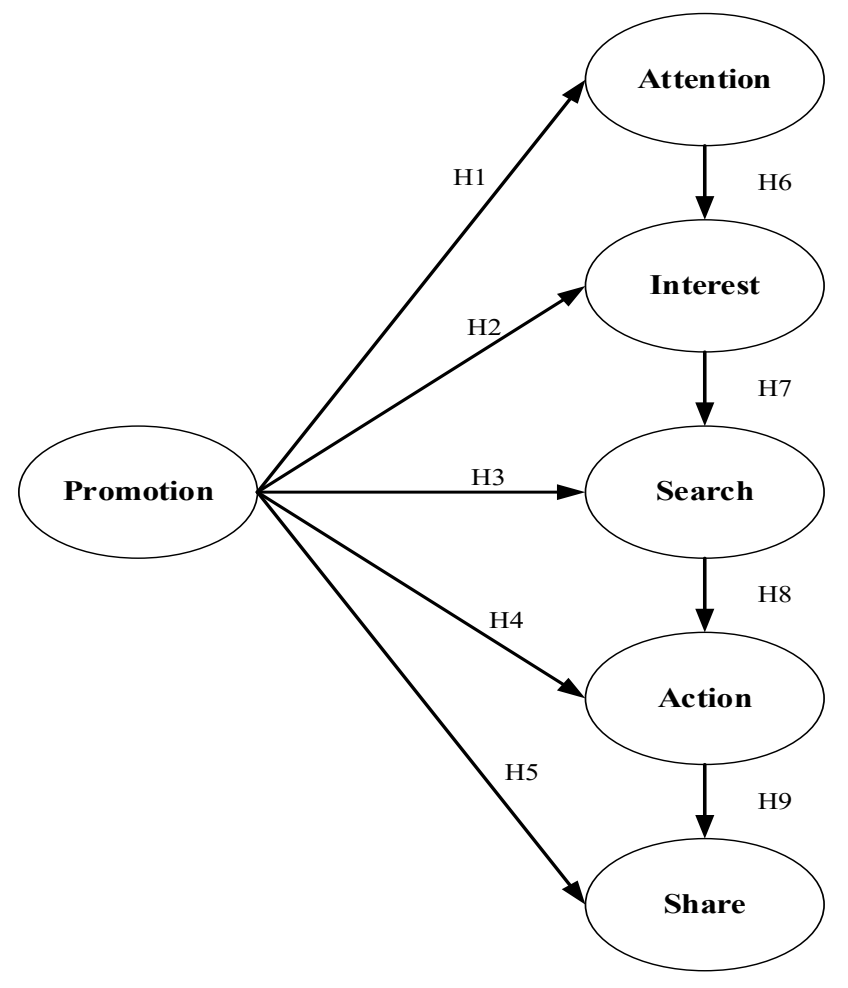

Figure 2 Conceptual Framework 
the research variable. The relationship between variables is based on Sugiyama and Andree (2011). The conceptual framework of the research is shown in Figure 2. The hypotheses that will be tested are as follows.

H1 : Promotion has a significant effect on attention.

$\mathrm{H} 2$ : Promotion has a significant impact on interest.

H3 : Promotion has a significant effect on search.

H4 : Promotion has a significant effect on action.

H5 : Promotion has a significant effect on share.

H6 : Attention has a significant effect on interest.

H7 : Interest has a significant effect on search.

H8 : Search has a significant effect on action.

H9 : Action has a significant effect on share.

\section{METHODS}

The research applies a descriptive analysis to determine the respondents' characteristics in tabular form using the SPSS application software. The used data are primary data obtained from questionnaires. Those questionnaires are distributed to Zomato Gold members through social media, using convenience sampling. The number of samples is 180 people.

Then, the relationship between variables is tested using the Structural Equation Modeling (SEM) model using Lisrel 8.8. The variables consist of the dependent variable and the independent variable. SEM can describe the relationship pattern between latent constructs and indicator variables. SEM measurements are carried out by the stages of validity testing, reliability testing, feasibility testing of SEM models, and significance testing. The tested variable relationship between the promotion, attention, interest, search, action, and share is based on the tested hypothesis. The operational definition for each research variable can be seen in Table 1 (see Appendices).

\section{RESULTS AND DISCUSSIONS}

Characteristics of respondents are based on the results of descriptive analysis. It includes gender, age, and frequency of using Zomato Gold promotions per month. The results can be seen in Table 2 (see Appendices).

Based on the results of descriptive analysis, the characteristics of respondents are dominated by women $(78,9 \%)$, whose ages are between $22-31$ years $(81,2 \%)$. Therefore, they can be said to be the millennial generation. Then, the frequency of using the Zomato Gold promotion per month is $61,1 \%$ or 1-2 times per month.

The value of the Standardized Loading Factor (SLF) is $\geq 0,5$. Then, the construct validity is valid according to Hair, Black, Babin, and Anderson (2013). Meanwhile, the value of Average Variance Extracted (AVE) is $\geq 0,5$, the value of Construct Reliability (CR) is $\geq 0,7$, and the value of the $t$-test is $>1,96$ to measure reliability. The evaluation of the measurement model for each variable is based on SEM, as seen in Figure 3.

The stages of evaluating the suitability level of the SEM model include the overall modelfit assessment, structural model suitability, and measurement model suitability (Hair et al., 2013). The Goodness of Fit Index (GFI) will be considered sufficient to assess the serviceability in a model if the requirement of four to five criteria is met. The results can be seen in Table 3 .

In the measurement of the Goodness of Fit Index (GFI) criteria based on Table 3 (see Appendices), it finds that the research model has met the eligibility requirements with 4-5 criteria with a good fit. The model fit test is conducted by looking at several criteria. The Root Mean Square Error of Approximation (RMSEA), Root Mean Square Residual (RMR), GFI, Normed Fit Index (NFI), Non-Normed Fit Index (NNFI), Comparative Fit Index (CFI), Incremental Fit Index (IFI), and Relative Fit Index (RFI) obtain a good fit. Meanwhile, Adjusted Goodness of Fit Index (AGFI) gets marginal fit.

The promotion variable consists of three indicators. The results of the analysis of the latent promotion variable towards the indicators based on Figure 3 are tested for validity and reliability with SLF, CR, and VE values. The results of the validity and reliability tests for the variable promotion are in Table 4. The results of testing promotion variable show a bigger t-value than 1,96 . The highest loading factor value is obtained from the $\mathrm{PRO} 2$ indicator (Zomato often advertises $1+1$ food promotions on social media). However, the PRO1 indicator has the lowest loading factor value (Zomato often promotes Zomato Gold).

Next, the attention variable consists of three indicators. The results of the analysis of the latent attention variable towards the indicators based on Figure 3 are tested for validity and reliability with SLF, CR, and VE values. The results of the validity and reliability tests for the attention variable are in Table 5 . The results for all indicators have a bigger t-value than 1,96. The highest loading factor value is obtained from the ATT1 indicator (Zomato consistently posts Zomato Gold promotional advertisement on social media). Meanwhile, the ATT3 indicator has the lowest loading factor value (consumers see and read $2+2$ drink promotional advertisements on social media).

Next, the interest variable consists of three indicators. The results of the analysis of the latent interest variable towards the indicators based on Figure 3 are tested for validity and reliability with SLF, $\mathrm{CR}$, and VE values. The results tests for the attention variable are in Table 6 . It shows that all indicators have a bigger $\mathrm{t}$-value than 1,96. The highest loading factor value is on the INT3 indicator (consumers are interested in the ratings of restaurants that work with Zomato Gold). Then, the lowest loading factor value is on the INT2 indicator (consumers are interested in reviews of restaurants that work with Zomato Gold). 


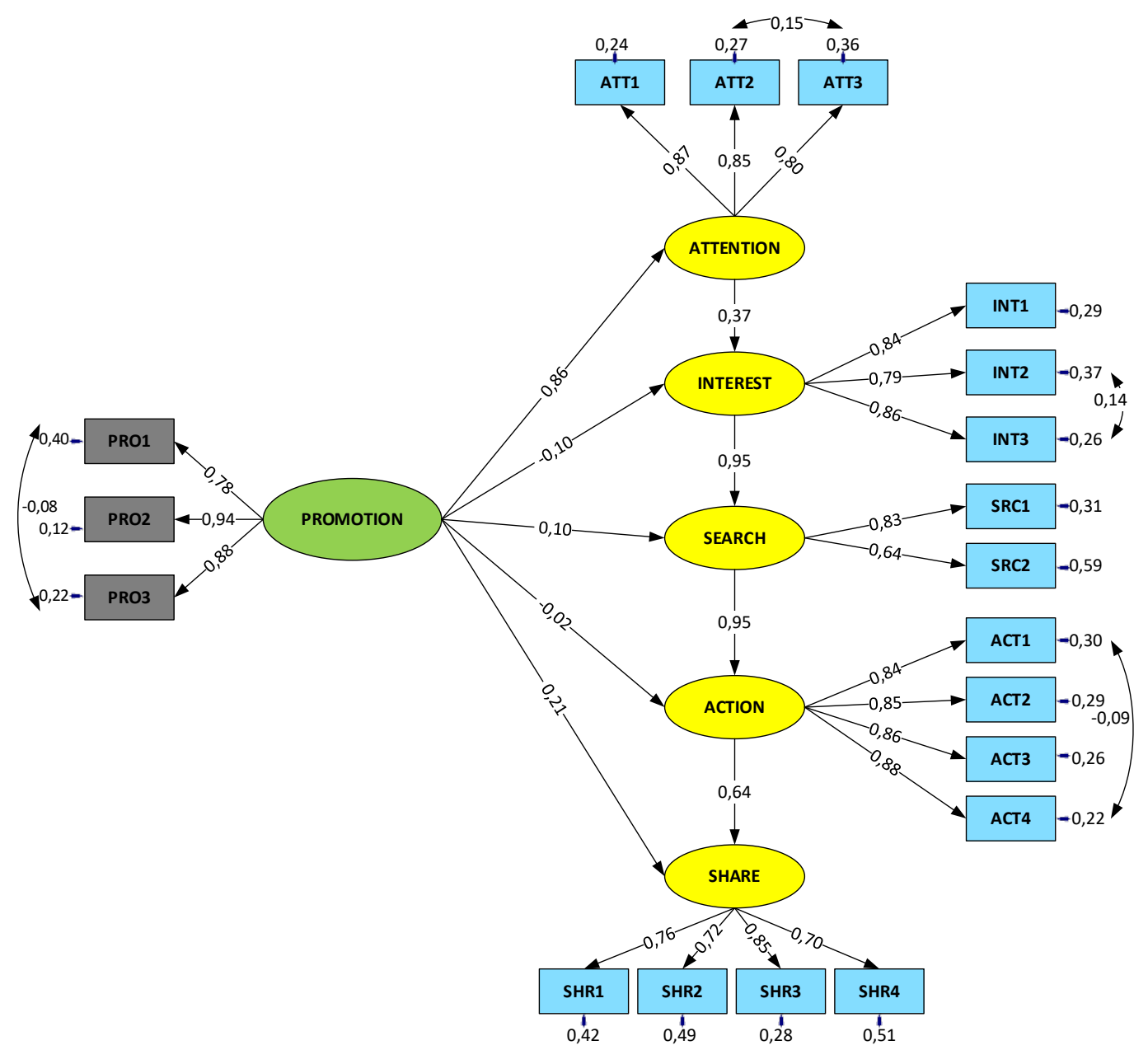

Figure 3 Structural Equation Modeling (SEM)

Table 4 Validity and Reliability Tests of Promotion Variable

\begin{tabular}{cccccc}
\hline Indicators & Loading Factor & T-Value & Error Variance & CR & VE \\
\hline PRO1 & 0,78 & 11.95 & 0,40 & 0,90 & 0,75 \\
PRO2 & 0,94 & 16.12 & 0,12 & & \\
PRO3 & 0,88 & 14.52 & 0,22 & & \\
\hline
\end{tabular}

Table 5 Validity and Reliability Tests of Attention Variable

\begin{tabular}{cccccc}
\hline Indicators & Loading Factor & T-Value & Error Variance & CR & VE \\
\hline ATT1 & 0,87 & 0,00 & 0,24 & 0,89 & 0,71 \\
ATT2 & 0,85 & 13,32 & 0,27 & & \\
ATT3 & 0,80 & 11,70 & 0,36 & & \\
\hline
\end{tabular}

Table 6 Validity and Reliability Tests of Interest Variable

\begin{tabular}{cccccc}
\hline Indicators & Loading Factor & T-Value & Error Variance & CR & VE \\
\hline INT1 & 0,84 & 0,00 & 0,29 & 0,87 & 0,69 \\
INT2 & 0,79 & 12,31 & 0,37 & & \\
INT3 & 0,86 & 14,00 & 0,26 & & \\
\hline
\end{tabular}


The search variable consists of two indicators. The results of the latent search variable analysis for the indicators based on Figure 3 are tested with the SLF, CR, and VE values for validity and reliability. The results of the validity and reliability tests for the attention variable are in Table 7 . The result indicates that all indicators have a bigger t-value than 1,96. The highest loading factor value is found in the SRC1 indicator (consumers look for additional information about the restaurant through the Zomato application). Meanwhile, the lowest loading factor value is from the SRC2 indicator (consumers seek further information by asking other people who have visited the restaurant).

The action variable consists of four indicators. The results of the analysis of the latent action variable on the indicators based on Figure 3 are tested with the values of SLF, CR, and VE for validity and reliability. The results of the validity and reliability tests for the attention variable are in Table 8 . The results show that all indicators have a bigger t-value than 1,96. The highest loading factor value is in the ACT4 indicator (consumers make purchases by visiting restaurants after reading reviews and ratings). Meanwhile, the lowest loading factor value is in the ACT2 indicator (consumers make purchases by visiting restaurants because they are interested in the Zomato Gold promotion).

The share variable consists of four indicators. The results of the latent share variable analysis based on Figure 3 are tested the validity and reliability with the SLF, CR, and VE values. The results of the validity and reliability tests for the share variable are in Table 9. The results indicate that all indicators have a bigger value than 1,96 . The highest loading factor value is in the SHR3 indicator (consumers will recommend restaurants that they have been visited). However, the lowest loading factor value is from the SHR4 indicator (consumers provide testimonials about Zomato Gold).

Then, hypothesis testing is done with an alpha (a) value of 0,05 . If the t-value is bigger than 1,96 , it is declared significant. The results of hypothesis testing can be seen in Table 10.
Table 10 shows that the promotion variable has a significant impact on two variables, namely attention and share variables. However, the promotion variable does not significantly affect interest, search, and action variables. Then, the attention variable does not impact interest significantly. Meanwhile, the interest variable has a significant effect on the search variable. Similarly, the search variable affects the action variable significantly. Then, action variable impacts share variable significantly.

Based on the H1 test results, the promotion variable has a significant effect on attention. It has a coefficient value of 0,86 and a t-value of 11,58 , which are higher than the t-table value of 1,96. $\mathrm{H} 1$ is accepted. Advertising in social media has succeeded in making consumers aware and pay attention, especially regarding $1+1$ food promotions. These results are supported by previous research that social media has a positive effect on consumers' attention (Abdurrahim, Najib, \& Djohar, 2019).

The result of $\mathrm{H} 2$ indicates that the promotion variable does not significantly affect the interest variable, with a coefficient value of $-0,10$ and t-value $-0,49$ (lower than the t-table value of 1,96 ). H2 is rejected. Promotional advertisement does not affect consumers' interest in Zomato Gold. Consumers will be more interested in promotions showing the hedonic and utilitarian benefits of the product (Sinha \& Verma, 2020).

Hence, Zomato needs to create promotional content with more information about the offered product to make consumers more interested. In this case, it is Zomato Gold.

Similarly, in H3, the promotion variable has no significant effect on the search variable, with a coefficient of 0,10 and a t-value of 1,59 , which is lower than the t-table value of 1,96 . H3 is rejected. Consumers do not seek further information about promotions advertised by Zomato. The results of hypothesis testing are supported by the previous research, which states that consumers will seek further information if a promotional advertisement can change their interest (Cheah, Ting, Cham, \& Memon, 2019).

Table 7 Validity and Reliability Tests of Search Variable

\begin{tabular}{cccccc}
\hline Indicators & Loading Factor & T-Value & Error Variance & CR & VE \\
\hline SRC1 & 0,83 & 0,00 & 0,31 & 0,71 & 0,55 \\
SRC2 & 0,64 & 9,32 & 0,59 & & \\
\hline
\end{tabular}

Table 8 Validity and Reliability Tests of Action Variable

\begin{tabular}{cccccc}
\hline Indicators & Loading Factor & T-Value & Error Variance & CR & VE \\
\hline ACT1 & 0,84 & 0,00 & 0,30 & 0,92 & 0,73 \\
ACT2 & 0,85 & 13,92 & 0,29 & & \\
ACT3 & 0,86 & 14,27 & 0,26 & & \\
ACT4 & 0,88 & 13,02 & 0,22 & & \\
\hline
\end{tabular}


Therefore, Zomato needs to create promotional content that consumers are interested in so that they will find more information about the promotions.

In $\mathrm{H} 4$, the promotion variable also does not affect the action variable significantly. It has a coefficient value of $-0,02$ and a t-value of $-0,33$ (lower than the t-table of 1,96). H4 is rejected. It implies that after seeing the promotional advertisement, consumers do not immediately come to the restaurant to make purchases and take advantage of Zomato Gold promotions. The relationship between advertisement content in social media and purchase intention is not significant (Raji, Rashid, \& Ishak, 2019).

Consumers do not immediately buy after seeing the advertisement. It may be because the information in the advertisement is unclear and limited. The appearance of social media has limitations, such as the number of displayed words and the duration of the show, so consumers need to find additional information to make purchase decisions.

The result of H5 shows that the promotion variable has a significant effect on the share variable. It has a coefficient value of 0,21 and a t-value of 3,08 , which are higher than the t-table value of 1,96. H5 is accepted. Consumers share promotional information with others. The behavior of social media users in sharing information is considered attractive (Diomidous et al., 2016).

So, Zomato promotional information is deemed attractive by consumers to share it with others.

In H6, the attention variable does not affect the interest variable significantly. It has a coefficient value of 0,37 and a t-value of 1,84 (lower than the t-table value of 1,96). H6 is rejected. The information created by marketers cannot attract consumers because the conveyed information is less detailed or does not explain its advantages (Pashootanizadeh \& Khalilian, 2018).

The information factor is not clear, and it can be influenced by limitations on social media to display information, such as a limited number of words or image resolution.

The result of $\mathrm{H} 7$ shows that the interest variable has a significant effect on the search variable, with a coefficient value of 0,95 and a t-value of 12,13 , which are higher than the t-table value of 1,96 . H7 is accepted. When consumers are interested in Zomato Gold promotions, restaurant reviews, and ratings, they will seek additional information about the restaurant through the Zomato application and ask people who have visited the restaurant. Hence, if the consumers are interested in a promotion, they will do a search activity (Liu, Polman, Liu, \& Jiao, 2018).

Based on the highest loading factor, consumers are more interested in restaurant ratings.

The result of $\mathrm{H} 8$ indicates that the search variable affects the action variable significantly. It has a coefficient value of 0,95 and a t-value of 12,06 , which are higher than the t-table value of 1,96 . H8 is accepted. After getting additional information about restaurants, consumers make purchases by visiting the restaurant to take advantage of Zomato Gold promotions. They obtain further information from the Zomato application, such as information about menus, prices, restaurant addresses, food pictures, restaurant atmosphere, reviews, and other consumers' ratings. They make purchases mostly because of reading the reviews and ratings. IoT allows them to find more additional information through various digital media so that they pay more attention to eWOM in culinary

Table 9 Validity and Reliability Tests of Share Variable

\begin{tabular}{cccccc}
\hline Indicators & Loading Factor & T-Value & Error Variance & CR & VE \\
\hline SHR1 & 0,76 & 0,00 & 0,42 & 0,84 & 0,57 \\
SHR2 & 0,72 & 9,40 & 0,49 & & \\
SHR3 & 0,85 & 11,08 & 0,28 & & \\
SHR4 & 0,70 & 9,15 & 0,51 & & \\
\hline
\end{tabular}

Table 10 Hypothesis Testing Results

\begin{tabular}{ccccc}
\hline Hypothesis & Variable & Coefficient & T-Value & Conclusion \\
\hline H1 & Promotion $\rightarrow$ Attention & 0,86 & 11,58 & Significant \\
H2 & Promotion $\rightarrow$ Interest & $-0,10$ & $-0,49$ & Not significant \\
H3 & Promotion $\rightarrow$ Search & 0,10 & 1,59 & Not significant \\
H4 & Promotion $\rightarrow$ Action & $-0,02$ & $-0,33$ & Not significant \\
H5 & Promotion $\rightarrow$ Share & 0,21 & 3,08 & Significant \\
H6 & Attention $\rightarrow$ Interest & 0,37 & 1,84 & Not significant \\
H7 & Interest $\rightarrow$ Search & 0,95 & 12,13 & Significant \\
H8 & Search $\rightarrow$ Action & 0,95 & 12,06 & Significant \\
H9 & Action $\rightarrow$ Share & 0,64 & 7,70 & Significant \\
\hline
\end{tabular}


tourism (Litvin, Goldsmith, \& Pan, 2018).

The credibility of information sources, positive quality of information, and strong arguments will influence purchasing decisions (Zhu, Chang, \& Luo, 2016).

In $\mathrm{H}$, the action variable has a significant effect on the share variable, with a coefficient value of 0,64 and a t-value of 7,70, which are higher than the t-table value of 1,96 . H9 is accepted. After tasting the products, consumers' evaluation and experience with the product will be informed and recommended to others. Social media allows them to share information with others. It becomes consumer behavior in the digital era (Jang, Lee, Kwak, \& Ko, 2019). Consumers more recommend restaurants that they have visited than writing reviews and ratings on the Zomato application. The experience of using a product will shape consumers' involvement in the form of eWOM and their willingness to share experiences and recommendations (Kim \& Fesenmaier, 2017). Prospective consumers' purchasing decisions can be driven by eWOM. EWOM can be a reference for companies to improve products and marketing strategies (Sun, Niu, Yao, \& Yan, 2019).

Managerial implications that can be used as an alternative to increase the effectiveness of promotional advertisement and consumers' purchases start with consumers' awareness and attention. Consumers' awareness and attention to the Zomato Gold promotional advertisement does not make them interested in the promotion. They are more interested in restaurant ratings and reviews and the $1+1$ food benefit from Zomato Gold. The main factor for consumers' interest is the rating and reviews. When consumers are interested, they will look for additional information about restaurants in the Zomato Gold application. Then, consumers make purchasing decisions to restaurants with reviews and ratings as the driving factors. After making a purchase, consumers will have the experience to share with others. However, consumers are more willing to recommend the restaurants they visit. Therefore, review and rating activities on the Zomato application are the second alternative for the consumers.

Consumers' opportunities to make purchases (action) are when they are already interested by just paying attention to social media promotions. Advertisements carried out on social media only encourage consumers' attention. Hence, Zomato can continue to utilize social media to make consumers aware of and pay attention to Zomato Gold products and maximize its social media features. A currently frequently used part is the story feature, which is on the main page of social media with a red button. It can be easily accessed by consumers when opening social media. Then, Zomato can also measure how many consumers that pay attention to the advertisement. It can be done by looking at the number of viewers on the feature to stimulate consumers to see a promotional advertisement on the story.

Another thing to measure whether consumers pay attention to and are aware of promotional advertisements is the question and answer content. For example, Zomato can provide questions about Zomato Gold to its consumers. The higher the level of consumers' attention is, the greater the chance of making consumers interested and continuing at the next purchase decision stage will be.

Moreover, people's interest in something is not only influenced by external factors but also internal factors, such as personality. Interest is one of the psychological aspects that can encourage people to achieve a goal (Afriany, 2018). Therefore, Zomato needs to examine more deeply what factors that can influence consumers' interest and improve the promotional content that is more informative about the products. Promotional content should be attractive to the younger generation with a striking and more informative color display. In addition, Zomato can use influencers to promote the products, in this case, Zomato Gold.

Then, the social media account of Zomato with many followers is Instagram, so it can maximize the features on social media and engage consumers in promotional activities as an alternative promotion to increase consumers' interest. The main factors that drive consumers' purchases the most are the ratings and reviews. So, promotional activities can involve consumers, such as Instagram live that invites influencers or food bloggers who review Zomato Gold, restaurants, and food. This promotional activity can make consumers get complete information about what Zomato promotes. In addition, artists or famous people can create consumers' awareness and interest in the products (Balasubramanian, Gopal, \& Reefana, 2016).

Zomato should post more promotional advertisements featuring images of the restaurant's food and atmosphere. Pictures of food and atmosphere become an exciting part of promoting culinary or restaurant. When Zomato uploads photos of food or atmosphere, consumers will look for additional information, such as restaurant addresses, menus, prices, ratings, and reviews. The obtained information will be evaluated and will lead to a purchase decision.

Apart from changing the content of promotional advertising, Zomato also needs to benefit Zomato members. Consumers are more interested in the benefits of $1+1$ food than $2+2$ drinks. So, Zomato needs other forms of benefits to consumers, such as discounts when making purchases.

Then, consumers will share information with others if the information is considered interesting or important. Promotional advertisement of Zomato is deemed attractive by Zomato Gold members, so they share it with others. However, sharing activities that Zomato needs to improve are providing ratings and writing reviews on the Zomato application because ratings and reviews are the main factors that encourage Zomato Gold members to make purchases. As an alternative way to increase rating and write reviews, Zomato can reward Zomato Gold members 
after doing these activities. Rewards can be given in the form of points for renewal membership payments or collaboration with digital wallets. These points can be converted into e-money that can be used during payment transactions at restaurants affiliated with Zomato.

\section{CONCLUSIONS}

The research results indicate that advertisements regarding Zomato Gold on social media based on the AISAS model are not significant enough to make consumers visit restaurants using the benefits of Zomato Gold. Promotional advertisement is only able to make consumers aware and pay attention to the advertisement. However, it does not make them interested in what is promoted. So, they do not take further actions, such as seeking additional information about Zomato Gold, making purchasing decisions by coming to restaurants that work with Zomato Gold to take advantage of the benefits, and sharing information and providing information to others about the Zomato Gold. Therefore, to increase consumers' purchases, Zomato must make consumers pay more attention to the promotional advertisements. The more the consumers pay attention to promotional advertisements, the higher the chances of consumers being interested in the promotion will be. Therefore, the opportunities for consumers' interest will increase. Then, it will also increase the opportunities for information search, consumers' purchases, and sharing information and recommendations to others about promotions and restaurants that consumers have visited.

The research limitation is that the respondents are only limited to the Zomato Gold members who have special advantages and other factors causing indirect promotions to attract consumers. Future research needs to study Zomato users who are not members of the Zomato Gold on promotions carried out by Zomato on social media regarding restaurants. Other factors that influence purchasing decisions can be analyzed with the AISAS model. Apart from promotions with the AISAS model, one of the factors is consumers' internal factors towards promotional advertisement that can encourage consumers' interest and purchase interest. The other factors can be based on consumers' making purchases that are influenced by external and internal factors.

\section{REFERENCES}

Abdurrahim, M. S., Najib, M., \& Djohar, S. (2019). Development of AISAS model to see the effect of tourism destination in social media. JAM: Jurnal Aplikasi Manajemen, 17(1), 133-143. https://doi. org/10.21776/ub.jam.2019.017.01.15

Abou-Elgheit, E. (2018). Understanding Egypt's emerging social shoppers. Middle East Journal of Management (MEJM), 5(3), 207-270. https://doi.org/10.1504/ mejm.2018.093611
Afriany. (2018). Consumer purchase behavior and interest concerning community at Bank Danamon Tbk in Solok. E-Jurnal Apresiasi Ekonomi, 6(1), 43-51. https://doi.org/10.31846/jae.v6i1.21

Akram, W., \& Kumar, R. (2017). A study on positive and negative effects of social media on society. International Journal of Computer Sciences and Engineering, 5(10), 351-354. https://doi. org/10.26438/ijcse/v5i10.351354

Algharabat, R., Rana, N. P., Dwivedi, Y. K., Alalwan, A. A., \& Qasem, Z. (2018). The effect of telepresence, social presence and involvement on consumer brand engagement: An empirical study of nonprofit organizations. Journal of Retailing and Consumer Services, 40(January), 139-149. https:// doi.org/10.1016/j.jretconser.2017.09.011

Ardianti, A. N., \& Widiartanto, W. (2019). Pengaruh online customer review dan online customer rating terhadap keputusan pembelian melalui marketplace Shopee. (Studi pada mahasiswa aktif FISIP Undip). Jurnal Ilmu Administrasi Bisnis, 8(2), 55-66.

Balasubramanian, P., Gopal, A. V., \& Reefana, S. (2016). A case study on misleading celebrity endorsements and its impact on consumer behavior. Bonfring International Journal of Industrial Engineering and Management Science, 6(3), 93-95.

Bhatti, A. (2018). Sales promotion and price discount effect on consumer purchase intention with the moderating role of social media in Pakistan. International Journal of Business Management, 3(4), 50-58.

Bu, Y., Parkinson, J., \& Thaichon, P. (2020). Digital content marketing as a catalyst for e-WOM in food tourism. Australasian Marketing Journal, 1-12. https://doi. org/10.1016/j.ausmj.2020.01.001

Cheah, J. H., Ting, H., Cham, T. H., \& Memon, M. A. (2019). The effect of selfie promotion and celebrity endorsed advertisement on decision-making processes: A model comparison. Internet Research, 29(3), 552577. https://doi.org/10.1108/IntR-12-2017-0530

Diomidous, M., Chardalias, K., Magita, A., Koutonias, P., Panagiotopoulou, P., \& Mantas, J. (2016). Social and psychological effects of the internet use. Acta Informatica Medica, 24(1), 66-69. https://doi. org/10.5455/aim.2016.24.66-69

Dwivedi, Y. K., Ismagilova, E., Hughes, D. L., Carlson, J., Filieri, R., Jacobson, J., ... \& Wang, Y. (2021). Setting the future of digital and social media marketing research: Perspectives and research propositions. International Journal of Information Management, 59(August), 1-37. https://doi.org/10.1016/j. ijinfomgt.2020.102168

Farki, A., Baihaqi, I., \& Wibawa, M. (2016). Pengaruh online customer review dan rating terhadap kepercayaan dan minat pembelian pada online marketplace di Indonesia. Jurnal Teknik ITS, 5(2), A614-A619. https://doi.org/10.12962/j23373539.v5i2.19671

Hair, J. F., Black, W. C., Babin, B. J., \& Anderson, R. E. (2013). Multivariate data analysis ( $7^{\text {th }}$ ed.). Pearson Education Limited.

Jang, W. E., Lee, J. S., Kwak, D. H., \& Ko, Y. J. (2019). Meaningful vs. hedonic consumption: The effects 
of elevation on online sharing and information searching behaviors. Telematics and Informatics, 45(December). tele.2019.101298

https://doi.org/10.1016/j.

Katadata. (2020). Ini media sosial paling populer sepanjang April 2020. Retrieved from https://databoks. katadata.co.id/datapublish/2020/05/25/ini-mediasosial-paling-populer-sepanjang-april-2020

Kim, J. J., \& Fesenmaier, D. R. (2017). Sharing tourism experiences: The posttrip experience. Journal of Travel Research, 56(1), 28-40. https://doi. org/10.1177/0047287515620491

Kotler, P., \& Keller, K. L. (2016). Marketing management (15 th ed.). Pearson.

Litvin, S. W., Goldsmith, R. E., \& Pan, B. (2018). A retrospective view of electronic word-of-mouth in hospitality and tourism management. International Journal of Contemporary Hospitality Management, 30(1), 313-325. https://doi.org/10.1108/ IJCHM-08-2016-0461

Liu, Y., Polman, E., Liu, Y., \& Jiao, J. (2018). Choosing for others and its relation to information search. Organizational Behavior and Human Decision Processes, 147(July), 65-75. https://doi. org/10.1016/j.obhdp.2018.05.005

Mandal, P., Joshi, N., \& Sheela, K. (2016). Understanding digital marketing-Theories and strategies. International Research Journal of Management Science \& Technology, 7(9), 50-60.

McAlister, L., Srinivasan, R., Jindal, N., \& Cannella, A. A. (2016). Advertising effectiveness: The moderating effect of firm strategy. Journal of Marketing Research, 53(2), 207-224. https://doi.org/10.1509/ jmr.13.0285

Nurhayati-Wolff, H. (2020). Indonesia: Number of Internet users 2015-2025. Retrieved from https://www. statista.com/statistics/254456/number-of-internetusers-in-indonesia/

Oke, A. O., Kamolshotiros, P., Popoola, O. Y., Ajagbe, A. M., \& Olujobi, J. O. (2016). Consumer behavior towards decision making and loyalty to particular brands. International Review of Management and Marketing, 6, 43-52.

Pashootanizadeh, M., \& Khalilian, S. (2018). Application of the AIDA model: Measuring the effectiveness of television programs in encouraging teenagers to use public libraries. Information and Learning Science, 119(11), 635-651. https://doi.org/10.1108/ILS-042018-0028

Piñeiro-Otero, T., \& Martínez-Rolán, X. (2016). Understanding digital marketing-Basics and actions. In C. Machado, \& J. P. Davim (Eds.), MBA: Theory and application of business and management principles. Springer International Publishing Switzerland.

Putri, V. M. (2019). 6 fakta tentang Zomato, aplikasi pencari restoran. Retrieved from https:// inet.detik.com/cyberlife/d-4624951/6-faktatentang-zomato-aplikasi-pencari-restoran? $\mathrm{ga}=2.140128307 .1075365106 .1623763869$ 1278403879.1623763869
Raji, R. A., Rashid, S., \& Ishak, S. (2019). The mediating effect of brand image on the relationships between social media advertising content, sales promotion content and behaviuoral intention. Journal of Research in Interactive Marketing, 13(3), 302-330. https://doi.org/10.1108/JRIM-01-2018-0004

Rangaswamy, A., Moch, N., Felten, C., Van Bruggen, G., Wieringa, J. E., \& Wirtz, J. (2020). The role of marketing in digital business platforms. Journal of Interactive Marketing, 51(August), 72-90. https:// doi.org/10.1016/j.intmar.2020.04.006

Ratchford, B. T. (2020). The history of academic research in marketing and its implications for the future. Spanish Journal of Marketing, 24(1), 3-36. https:// doi.org/10.1108/SJME-11-2019-0096

Reily, M. (2019). Adopsi teknologi digital, tips Zomato agar bisnis kuliner makin sukses. Retrieved from https:// katadata.co.id/desysetyowati/berita/5e9a551520ef2/ naikkan-jumlah-pengguna-zomato-ajak-bisniskuliner-adopsi-teknologi

Shah, D., \& Murthi, B. P. S. (2020). Marketing in a datadriven digital world: Implications for the role and scope of marketing. Journal of Business Research, 125(March), 772-779. https://doi.org/10.1016/j. jbusres.2020.06.062

Sharma, A., Sharma, S., \& Chaudhary, M. (2020). Are small travel agencies ready for digital marketing? Views of travel agency managers. Tourism Management, 79(August), 1-10. https://doi.org/10.1016/j. tourman.2020.104078

Sinha, S. K., \& Verma, P. (2020). Impact of sales promotion's benefits on perceived value: Does product category moderate the results? Journal of Retailing and Consumer Services, 52(January), 1-11. https://doi. org/10.1016/j.jretconser.2019.101887

Stephen, A. T. (2016). The role of digital and social media marketing in consumer behavior. Current Opinion in Psychology, 10(August), 17-21. https://doi. org/10.1016/j.copsyc.2015.10.016

Sugiyama, K., \& Andree, T. (2011). Dentsu way: Secrets of cross switch marketing from the world's most innovative advertising agency. McGraw-Hill.

Sun, Q., Niu, J., Yao, Z., \& Yan, H. (2019). Exploring eWOM in online customer reviews: Sentiment analysis at a fine-grained level. Engineering Applications of Artificial Intelligence, 81(May), 68-78. https://doi. org/10.1016/j.engappai.2019.02.004

Tang, S., Hao, P., \& Feng, J. (2020). Consumer behavior of rural migrant workers in urban China. Cities, 106(November), 1-10. https://doi.org/10.1016/j. cities.2020.102856

Zhang, J., Zheng, W., \& Wang, S. (2020). The study of the effect of online review on purchase behavior: Comparing the two research methods. International Journal of Crowd Science, 4(1), 73-86. https://doi. org/10.1108/ijcs-10-2019-0027

Zhu, D. H., Chang, Y. P., \& Luo, J. J. (2016). Understanding the influence of $\mathrm{C} 2 \mathrm{C}$ communication on purchase decision in online communities from a perspective of information adoption model. Telematics and Informatics, 33(1), 8-16. https://doi.org/10.1016/j. tele.2015.06.001 


\section{APPENDICES}

Table 1 Research Variables and Indicators

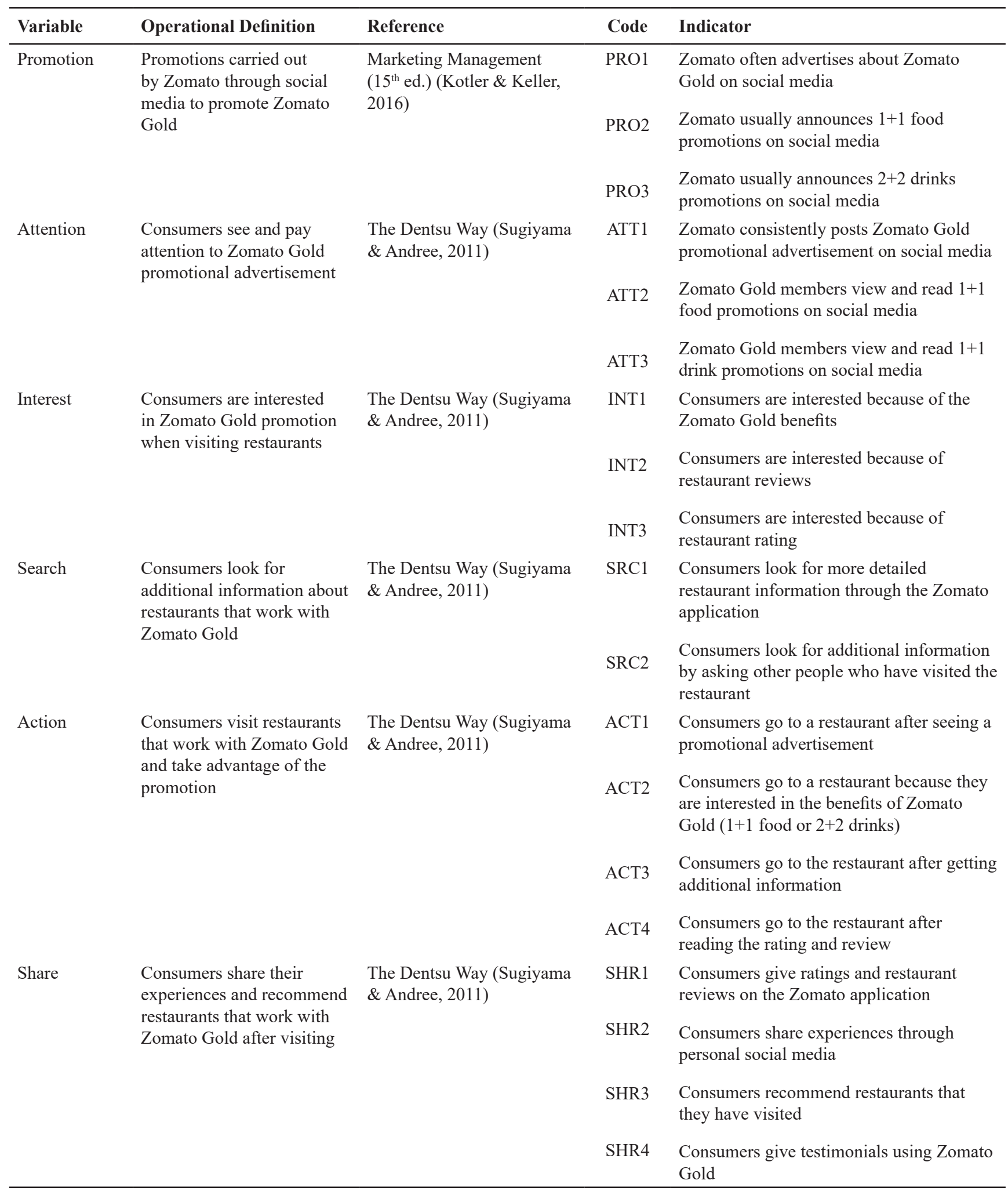


Table 2 Characteristics of Respondents.

\begin{tabular}{|c|c|c|c|c|}
\hline No & Characteristics & & Frequency & $(\%)$ \\
\hline \multirow[t]{2}{*}{1} & Gender & Male & 38 & 21,1 \\
\hline & & Female & 142 & 78,9 \\
\hline \multirow[t]{5}{*}{2} & Age & 17-21 years & 9 & 5 \\
\hline & & $22-26$ years & 73 & 40,6 \\
\hline & & $27-31$ years & 73 & 40,6 \\
\hline & & $32-36$ years & 17 & 9,4 \\
\hline & & Over 36 years & 8 & 4,4 \\
\hline \multirow[t]{3}{*}{3} & Frequency of using Zomato Gold promo per month & $1-2$ times & 110 & 61,1 \\
\hline & & $3-5$ times & 48 & 26,7 \\
\hline & & More than 5 times & 22 & 12,2 \\
\hline
\end{tabular}

Table 3 Goodness of Fit

\begin{tabular}{lccc}
\hline Goodness of Fit Measures & Cut-off Value & Result & Conclusion \\
\hline Root Mean Square Error of Approximation (RMSEA) & $\leq 0,08$ & 0,065 & Good Fit \\
Root Mean Square Residual (RMR) & $\leq 0,05$ or $\leq 0,1$ & 0,085 & Good Fit \\
Goodness of Fit Index (GFI) & $\geq 0,90$ & 0,90 & Good Fit \\
Adjusted Goodness of Fit Index (AGFI) & $\geq 0,90$ & 0,85 & Marginal Fit \\
Normed Fit Index (NFI) & $\geq 0,90$ & 0,97 & Good Fit \\
Non-Normed Fit Index (NNFI) & $\geq 0,90$ & 0,98 & Good Fit \\
Comparative Fit Index (CFI) & $\geq 0,90$ & 0,99 & Good Fit \\
Incremental Fit Index (IFI) & $\geq 0,90$ & 0,99 & Good Fit \\
Relative Fit Index (RFI) & $\geq 0,90$ & 0,96 & Good Fit \\
\hline
\end{tabular}

